\title{
Analysis of Funding Strategy, Credit Performance, and Banking Profitability. (Case Study of CIMB-NIAGA Bank in Indonesia)
}

\author{
HERRY ACHMAD BUCHORY \\ Department of Magister Management, STIE EKUITAS, Bandung, INDONESIA. \\ E-mail: achmad_buchory@yahoo.com
}

\begin{abstract}
This study is to analysis funding strategy and credit performance, and its effect on Banking Profitability. The indicator of funding strategy measured with the ratio of time deposits with a total of third-party funds (DTPF) or a third-party fund structure (TPFS), credit performance measured by credit growth (CG) and non-performing loans rate (NPL), while banking profitability with return on assets (ROA).

The descriptive and verification methods with the quantitative approach will be used in this research. Secondary data sources are from the quarterly published financial statements of the CIMB Niaga Bank in Indonesia of 2012 - June 2020 period, and multiple regression used for data analysis. The study results found TPFS partially has a negative but not significant effect on ROA. CG partially has a positive but not significant effect on ROA while NPL partially has a negative and significant effect on return on assets. Simultaneously TPFS, CG and NPL have a significant effect on ROA. The ROA is influenced by TPFS, CG, and NPL of $71.2 \%$ while the remaining $28.8 \%$ is influenced by other factors.
\end{abstract}

Keywords: Banking Profitability, Credit Performance, Credit Growth, Non-Performing Loans, Return on Assets, Third-Party Funds.

JEL Classification: G21, G32 


\section{Introduction}

The purpose of establishing a company is to make a profit. Likewise, the establishment of a bank. With the profits obtained, the bank can fulfil its obligations to shareholders by depositing dividends and maintaining the continuity of the bank's business, which in turn will increase the welfare of shareholders and company value. Therefore, the ability of a bank to gain profit or profitability is a major concern for bank managers. This profitability is an important factor in assessment of commercial bank soundness level (Financial Services Authority of Indonesia, 2017). Bank profitability is mainly obtained from the banking intermediation process, namely the process of raising funds and channelling funds, especially credit. When raising funds, the bank pays interest costs and when distributing funds, the bank earns interest income. The structure of third-party funds will affect the cost of funds, likewise, credit performance will affect bank revenues which in turn will affect bank profitability.

CIMB Niaga Bank is one of the largest banks in Indonesia, most of shares (91.48\%) are owned by CIMB Group Holdings Berhad Malaysia. CIMB Niaga Bank is a bank that has been included in the Commercial Bank Group of Busines - 4 (BUKU IV) since 2017 with a core capital of IDR 35,344,546 million and total assets of IDR 272,039,821 million, in June 2020 (www.cimbniaga.co.id).

The funding strategy that comes from third-party funds by reducing the composition or structure of expensive funds in the form of time deposits to low-cost funds in the form of current accounts and savings is a good strategy taken by management to reduce the cost of funds. The ratio of time deposits to total third party funds in December 2012 was $56.67 \%$, continuously decreasing to $34.85 \%$ in June 2020. This strategy should have an impact on increasing bank profitability. However, from data up to June 2020 , the profitability achieved has decreased. Profitability, as measured by ROA in December 2012 , was $3.11 \%$ to only $1.67 \%$ in June 2020 .

This phenomenon indicates that other variables affect bank profitability. The author suspects that the credit business owned by the bank has less than optimal performance. This is based on bank credit data for June 2020, namely credit growth of minus $8.84 \%$ while NPL becomes $3.89 \%$. Therefore this study aims to determine the effect of funding strategy and credit performance on bank profitability. The funding strategy is measured with the ratio of time deposits with a total of third-party funds (DTPF) or third-party funds structure (TPFS), credit performance measured by credit growth (CG) and nonperforming loans rate (NPL), while banking profitability with return on assets (ROA).

\section{Literature Review}

Banks are depository financial institution that collect and channel funds directly from the public. Banks collect the savings of individuals as well as businesses and then lend these pooled saving to other individuals and businesses. They make money by charging a rate of interest to borrowers that exceeds the rate they pay to savers (Titman, 2018).

The traditional role of banks has been to take deposits and make loans. The interest charged on the loans is greater than the interest paid on deposits. The difference between the two has to cover administrative cost and loan losses (i.e. losses when borrowers fail to make the agreed payment on interest and principal), while providing a satisfactory return on equity (Hull, 2012; Qureshi, Muhammad Imran, et al. 2020).

Most of the funds collected by banks come from third-party funds which are the main source of funds for bank credit. Time deposits are a type of third-party funds with high-interest rates compared to other types such as demand deposits or savings. Therefore, the structure of third-party funds which is dominated by time deposits will reduce bank profitability due to high cost of funds. Profitability is the bank's ability to make a profit.

There are several basic measures of bank profitability. The first is called return on assets (ROA). ROA is an important measure for how efficiently a particular bank use its assets (Cecchetti, Schoenholtz, \& Fackler, 2011). Bank profitability is influenced not only by the cost of funds but also by 
bank income, which mostly comes from loan interest income. Therefore, the less than optimal credit performance due to the limited amount of credit distribution and the quality of credit repayments will also affect the decline in bank profitability. The quality of credit payments can be seen from the level of non-performing loans (Buchory, 2016).

\subsection{The Effect of the Third-Party Funds Structure (TPFS) on Return on Asset (ROA)}

Third party funds are the largest source of funds for banks. The greater the amount of funds raised, the greater the cost of funds to be paid, especially if the fund structure is dominated by expensive funds such as time deposits, then the cost of funds will be higher and will reduce bank profitability. This is evidenced by the results of the research that has been done, although the conclusions are inconsistent.

Several research results which state that third-party funds have a positive and significant effect on profitability are stated by (Pujiati, 2020) that third-party funds have a positive effect on the profitability of commercial banks in Indonesia. Then the results of (Hermuningsih, 2019) show a significant positive effect of third- party funds on profitability at Indonesian Sharia Banks during the 2013-2016 period. Likewise, according to (Magdalena, Marpaung, \& Indira, 2019), third party funds have a significant positive effect on the profitability on the Indonesia Stock Exchange. Furthermore, according to (Muda, Shaharuddin, \& Embaya, 2013), the results of their research stated that there was a significant effect of deposits on the profitability of banks in Malaysia. Likewise, the study of (Gul, Irshad, \& Zaman, 2011), deposits have a positive and significant effect on the profitability of banks in Pakistan.

Whereas some of the results of previous studies show different results, such as those conducted by (Erna, Naelati, \& Azmi, 2020) which state that third party funds do not have a significant effect on ROA of Islamic Commercial Bank Profitability in Indonesia during 2012-2018. Then, (Buchory, 2017) states that partially the structure of third-party funds (STPF) has a negative and significant effect on the measure of profitability with a net interest margin (NIM). Likewise, according to (Aslam, 2016), saving is a factor that does not have a significant effect on ROA and ROE, and savings have a negative effect on ROA and ROE. Furthermore, according to (Dawood, 2014), bank deposits do not show any influence on the profitability of commercial banks in Pakistan for the period (2009-2012).

Based on the theoretical basis and the results of previous research, it can be formulated hypotheses as follows:

H1: TPFS has a negative and significant effect on ROA

\subsection{The Effect of Credit Growth on Return on Asset (ROA)}

Credit or loans are the dominant assets in the most depository institutions' portfolio, representing on average 50 to 75 percent of total assets (Koch, 2014). Therefore, credit interest income will provide the largest contribution to bank profitability. The growth of lending and the quality of payment on loan principal and interest will affect bank profitability. This is evident from the results of research that has been done through a different result. Research result by (Wijayanti \& Mardiana, 2020) showed that loan growth had a significant positive effect on bank profitability, indirect effect loan growth had a significant positive effect on bank profitability with credit quality as an intervening variable, of commercial banks in Indonesia during the period from 2014 to 2018. Furthermore, according to (Erzha, Sudarma, \& Rahman, 2019), the result shows that the loan has a positive effect on conventional bank profitability period 2013 - 2017 in Indonesia. Then according to (Muda et al., 2013), states loan has significant effect on bank profitability, in the domestic banks only, in Malaysia. And according to (Gul et al., 2011), loans have a positive and significant effect on the profitability of banks in Pakistan. Meanwhile, according to (Hendrawati \& Djamaludin, 2020) partially, credit growth has no significant effect on bank profitability listed on Indonesian Stock Exchange period 2009-2013. Likewise, according to (Hồ, Đặng, Trần, Phạm, \& Hoàng, 2020) states the credit growth has negative relationships with the profitability of people's credit funds in Vietnam. 
Based on the theoretical basis and the results of previous research, it can be formulated hypotheses as follows:

H2: CG has a positive and significant effect on ROA

\subsection{The Effect of Non-Performing Loan on Return on Asset (ROA)}

In conducting the credit business, banks face credit risk also called default risk, arises from the uncertainty involved in repayment of the bank's dues by the counterparty on time. The Basel Committee on Banking Supervision (BCBS) has to define credit risk as a potential that a bank borrower or counterparty will fail to meet its obligation under the agreed terms (Ghosh, 2012). The internal factors and external factors, either singly or jointly, increase the incidences of credit defaults. The impact of credit risk is ultimately reflected through a loss of principal, loss of earnings, a decline in the market value of assets, burden of loan loss provisions (Ghosh, 2012). Non-performing loans can be used as a measure of the credit quality of a bank (Buchory, 2016). Therefore, the level of NPLs will affect the profitability of banks. (Buchory, 2016).

Several studies state that credit quality or NPLs effect on bank profitability, as has been done by (Kidane, 2020), the findings showed that credit risk management has significant impact on profitability of commercial banks in Ethiopia. Then (Iskandar, Che-Yahya, \& Ab Wahid) states that credit risk was significant toward profitability Commercial Banks' in Malaysia. Likewise, (Islam \& Rana, 2017) the empirical findings non-performing loans to total loans (NPL) on profitability was observed as the most significant among various variables of Commercial Banks in Bangladesh. Furthermore, (Isanzu, 2017), reveal non-performing loan has a significant impact of on financial performance of Chinese commercial Banks. Likewise according to (Ozgur \& Gorus, 2016), empirical results suggested that, non-performing loans has a significant impact over return on assets evidence from Turkey. (Akhtar, Ali, \& Sadaqat, 2011), states that NPLs ratio is found to have significant effect on the profitability of commercial banks in Pakistan. The result of (Saleh \& Abu Afifa, 2020) also indicate that credit risk has an impact on bank profitability: Evidence from an emerging market period (2010-2018).

Several research results which stated that NPL had a negative effect on profitability was carried out by (De Leon, 2020), the results show that credit risk negatively affect Return on Equity (ROE) at $5 \%$ level of significance, the case of the ASEAN banks. Then, (Munangi \& Bongani, 2020) the results of the study documented that credit risk was negatively related to financial performance. Likewise, (Ekinci \& Poyraz, 2019), there is a negative and significant relationship between credit risk (NPL) and return on asset (ROA) of Deposit Banks in Turkey. Furthermore, (Poudel, 2018) found that credit risk has the significant negative impact on profitability of commercial banks in Nepal. Likewise, according to (Kadioglu, Telceken, \& Ocal, 2017) found that there is a significant, negative relationship between nonperforming loans and bank profitability which is measured by return on equity and return on asset in Turkey period $2005-2016$. And, (Rwayitare, 2016) the study revealed that an increased exposure to credit risk reduces bank profitability in Rwanda.

Meanwhile, the research results which state that NPL has no positive effect means that it is not in accordance with the theory found by (Buchory, 2016) states that the partially NPLs have positive and significant effect to ROA of Regional Development Bank in Indonesia. Likewise, (Boahene, Dasah, \& Agyei, 2012) states that credit risk (non-performing loan rate) has a positive and significant relationship with bank profitability in Ghana. Likewise according to (Badawi, 2017), the results showed that NPL variable does not significant affect to ROE variable on Devised Banks in Indonesia Stock Exchange. Furthermore, (Kutum, 2017), found a weak but positive relationship between credit risk as measured by non-performing loans and profitability as measured by return on assets of Banks Listed on the Palestine Exchange. Then, (Harahap \& Hairunnisah, 2017) the results of the analysis showed that nonperforming loans have no negative effect on profitability in banking companies on the Indonesia Stock Exchange. And, (Isanzu, 2017), the study findings reveal non-performing loan has a significant impact of on financial performance of Chinese commercial Banks. 
Based on the theoretical basis and the results of previous research, it can be formulated hypotheses as follows:

H3: NPL has a negative and significant effect on ROA

And finally, based on theoretical support, the results of previous research and empirical facts that occurred in the unit of analysis as described above, to determine the effect between variables, the hypothesis that can be formulated is as follows:

H4: TPFS, CG, and NPL have a significant effect on ROA

\section{Methodology}

Descriptive and verification methods with a quantitative approach are used in this study. Secondary data from the financial statement published quarterly by Bank CIMB Niaga for the period 2012 - June 2020. For data analysis, multiple linear regression was used, then the t-test and $f$ test statistic to test the hypothesis. While the regression equation is:

$$
Y=a+\beta X_{1}+\beta X_{2}+\beta X_{3}+e
$$

$\mathrm{Y}=$ Return on Assets (ROA); $\mathrm{a}=$ constant which is the value of the variable $\mathrm{Y}$ if the variable $\mathrm{X}$ is 0 (zero); $\beta=$ regression line coefficient; $X_{1}=$ TPFS; $X_{2}=C G ; X_{3}=N P L ;$ and, $e=$ Residual

\section{Results and Findings}

From the data in Table 1 below, it can be stated as follows:

Table 1. Development of The Third-Party Funds Structure (TPFS), Credit Growth (CG), Non-Performing Loan (NPL), and Return on Assets (ROA) CIMB Niaga Bank Period 2012 - June 2020

\begin{tabular}{|c|c|c|c|c|}
\hline Years & TPFS (\%) & CG (\%) & NPL (\%) & ROA (\%) \\
\hline 2012 & 56.67 & 3.03 & 2.33 & 3.11 \\
\hline 2013 & 55.50 & 8.86 & 2.29 & 2.75 \\
\hline 2014 & 54.44 & 7.51 & 4.01 & 1.60 \\
\hline 2015 & 52.44 & 13.82 & 3.82 & 0.21 \\
\hline 2016 & 47.40 & $(0.63)$ & 3.93 & 1.20 \\
\hline 2017 & 44.74 & $(0.03)$ & 3.78 & 1.70 \\
\hline 2018 & 44.48 & $(0.61)$ & 3.11 & 1.85 \\
\hline 2019 & 43.08 & $(3.38)$ & 2.79 & 1.86 \\
\hline $2020^{*}$ & 34.85 & $(8.84)$ & 3.89 & 1.67 \\
\hline Maximum & 56.67 & 8.86 & 4.01 & 3.11 \\
\hline Minimum & 34.85 & $(8.84)$ & 2.29 & 0.21 \\
\hline Average & 48.17 & 2.19 & 3.33 & 1.77 \\
\hline
\end{tabular}

*) until June 2020

Source: Quarterly Published Financial Statement, period 2012 - June 2020, www.cimb.co.id, processed, 2020)

Based on the published financial reports of CIMB Niaga Bank for the period 2012-2020, Third-Party Funds raised in 2012 amounting to IDR 128,699,772 billion increased to IDR 171,800,653 billion in June 2020 or an increase of $33.49 \%$. This increase in funds is the main source for credit to achieve bank profitability. The funding strategy carried out by CIMB Niaga Bank by reducing the ratio of time deposits to total third party funds from $56.67 \%$ in 2012 to $34.85 \%$ in June 2020 made the fund structure shift from expensive funds to cheap funds. This funding strategy can reduce the cost of funds paid by the bank so that the bank's profitability should increase. However, if you pay attention to empirical data, the profitability achieved by CIMB Niaga Bank has decreased, from $3.11 \%$ in 2012 to $1.67 \%$ in June 2020. The highest ROA was achieved in 2012 at $3.11 \%$ and the lowest ROA was achieved in 2013 
at $0.21 \%$. This decline in profitability was caused by less than optimal credit growth. The growth in third party funds should have been followed by growth in credit. The average credit growth during the 2012 - June 2020 period was only 2.19\%. Even the 2016 - June 2020 period experienced negative growth. The highest credit growth was achieved in 2015 at $13.82 \%$ and the lowest growth was negative at $8.84 \%$. The decline in profitability was also caused by an increase in non-performing loans. During the period 2012 - June 2020, the average NPL was 3.3\%. The highest NPL occurred in 2014 at 4.01\%, and the lowest NPL was in 2013 at $2.29 \%$. Although the average NPL is still below the authority's requirement of $5 \%$, the increase in NPL causes through a loss of principal, loss of earnings, a decline in the market value of assets, burden of loan loss provisions (Ghosh, 2012)

From the results of statistical data processing (Table 2), the following equation is made:

$$
\mathrm{ROA}=5.495-.004 \mathrm{TPFS}+0.47 \mathrm{CG}-1,076 \mathrm{NPL}
$$

- The value of the constant is 5.495 positive. This means that if TPFS and NPL have zero values, then the ROA will increase by 5.495. TPFS regression co-efficient -.004 means that if the TPFS increases one unit, the ROA decreases .004 . The regression co-efficient CG is 0.47 which means that if the CG increases by one unit, the ROA increases 0.47 . NPL regression co-efficient is -1.076 which means that if the NPL increases by one unit, the ROA decreases 1.076.

- Coefficient of Correlation (R) of TPFS, CG, and NPL, to ROA, is .844, which refers to having a strong correlation (Sugiyono, 2013). The determination coefficient (R-Square) is .712 meaning the ROA is influenced by TPFS, CG, and NPL of $71.2 \%$ while the remaining $28.8 \%$ is influenced by other factors.

- The partial test of the effect of TPFS on the ROA obtained a t-test value of -.225, which is lower than t-table (2.048) with a significant value of .125 higher .05. Thus, the $\mathrm{H} 1$ hypothesis TPFS has a negative and significant effect on ROA is rejected. This means that although CIMB Niaga Bank has lowered its fund structure to cheap funds, its impact on profitability is not significant. This study supports by previous studies conducted by (Aslam, 2016; Dawood, 2014; Erna et al., 2020) state that TPFS has a negative and but not significant effect on ROA. But contrary to the results of research conducted by (Gul et al., 2011; Hermuningsih, 2019; Magdalena et al., 2019; Muda et al., 2013; Pujiati, 2020), state that third-party funds have a positive and significant effect on profitability.

- The partial test of the effect of CG on the ROA obtained a t-test value of 1.582, which is lower than t-table (2.048) with a significant value of .824 higher .05. Thus, $\mathrm{H} 2$ hypothesis states CG has a positive and significant effect on ROA is rejected. This means that although CIMB Niaga Bank channelling credit, it was not optimal in supporting increased profitability. This study supports by previous studies conducted by (Hendrawati \& Djamaludin, 2020; Hồ et al., 2020) states that partially, credit growth has no significant effect on bank profitability. But contrary to the results of research conducted by (Erzha et al., 2019; Gul et al., 2011; Muda et al., 2013; Wijayanti \& Mardiana, 2020), states that credit has a positive and significant effect on the profitability.

- The test of the effect of NPL on the ROA obtained a t-test value of -.7.754, which is higher than t-table (2.048) with a significant value of .000 lower .05. Thus, H3 hypothesis states NPL has a negative and significant effect on ROA is accepted. This means that the increase in NPL at CIMB Niaga Bank significantly reduced profitability. This study supports by previous studies conducted by (De Leon, 2020; Ekinci \& Poyraz, 2019; Kadioglu et al., 2017; Poudel, 2018; Rwayitare, 2016) state that NPL has a negative and significant effect on ROA. But contrary to the results of research conducted by (Badawi, 2017; Boahene et al., 2012; Buchory, 2016; Harahap \& Hairunnisah, 2017; Isanzu, 2017; Kutum, 2017) states that credit risk (non-performing loan rate) has a positive and significant effect on ROA.

- F-count was 23.128 higher than the F-table (2.91) with a significant value of .000 . Thus, H4 hypothesis states TPFS, CG, and NPL have a significant effect on ROA is accepted. 
Table 2: The Result Summary of Statistical Data Processing, The Effect TPFS, CG, and NPL on ROA

\begin{tabular}{|c|c|c|c|c|}
\hline Description & Value & TPFS & CG & NPL \\
\hline Regression Coefficients & $\begin{array}{c}5.495 \\
\text { (Constant) }\end{array}$ & -.004 & .047 & -1.076 \\
\hline $\mathrm{R}$ & 0.844 & & & \\
\hline R-Square & 0.712 & & & \\
\hline $\mathrm{T}-\mathrm{Test}$ & $\begin{array}{c}4.976 \\
\text { (Constant) }\end{array}$ & -.225 & 1.582 & -7.754 \\
\hline Sig. & .000 & .824 & .125 & .000 \\
\hline$F-$ Test & 23.128 & & & \\
\hline Sig. & .000 & & & \\
\hline
\end{tabular}

Source: Output SPSS Ver. 25.0

\section{Conclusion}

The findings of this study are the funding strategy carried out by Bank CIMB Niaga by reducing expensive funds in the form of deposits was not able to increase bank profitability as a result of low credit growth and increased NPLs. The conclusion of this study stated that partially TPFS has a negative but not significant effect on ROA, meaning that even though CIMB Niaga Bank has succeeded in reducing expensive funds and replacing them with cheap funds so that the cost of funds decreases, the reduction in the cost of funds is not able to increase ROA because the ROA achieved by the bank is not only affected by the cost of funds. Partially CG has a positive but not significant effect on ROA, meaning that although credit growth can increase ROA, the increase in ROA is not significant due to low and even negative credit growth. Meanwhile, NPL partially has a negative and significant effect on return on assets, meaning that NPL will reduce bank income and increase the cost of reserves for nonperforming loans so that bank profits and profitability will decrease significantly. Simultaneously TPFS, CG and NPL have a significant effect on ROA.

ROA is influenced by TPFS, CG, and NPL of $71.2 \%$ while the remaining $28.8 \%$ is influenced by other factors

\section{References}

1. Akhtar, M. F., Ali, K., \& Sadaqat, S. (2011). Factors influencing the profitability of conventional banks of Pakistan. International Research Journal of Finance and Economics, 66, 117-124.

2. Aslam, M. K., Inamullah, and Mudsir Ismail. (2016). Determinants Affecting the Profitability of Islamic Banks: Evidence from Pakistan. International Journal of Operations and Logistics Management, 5(2), 115-127.

3. Badawi, A. (2017). Effect of Credit Risk, Liquidity Risk, and Market Risk Banking to Profitability Bank (Study on Devised Banks in Indonesia Stock Exchange). European Journal of Business and Management, 9(29), 1-8.

4. Boahene, S. H., Dasah, J., \& Agyei, S. K. (2012). Credit risk and profitability of selected banks in Ghana. Research Journal of finance and accounting, 3(7), 6-14.

5. Buchory, H. A. (2016). Determinants of banking profitability in Indonesian regional development bank. Актуальні проблеми економіки(3), 308-318.

6. Buchory, H. A. (2017). Structure of Third Party Funds, Financing Composition and Non Performing Financing on Islamic Banking Financial Performance. Advanced Science Letters, 23(9), 8837-8842.

7. Cecchetti, S. G., Schoenholtz, K. L., \& Fackler, J. (2011). Money, banking, and financial markets (Vol. 4): McGraw-Hill/Irwin. 
8. Dawood, U. (2014). Factors impacting profitability of commercial banks in Pakistan for the period of (2009-2012). International Journal of Scientific and Research Publications, 4(3), 1-7.

9. De Leon, M. (2020). The impact of credit risk and macroeconomic factors on profitability: the case of the ASEAN banks. Banks and Bank Systems, 15(1), 21-29.

10.Ekinci, R., \& Poyraz, G. (2019). The Effect of Credit Risk on Financial Performance of Deposit Banks In Turkey. Procedia Computer Science, 158, 979-987.

11.Erna, H., Naelati, T., \& Azmi, F. (2020). The Determinants of Islamic Commercial Bank Profitability in Indonesia during 2012-2018. SIMILIARITY.

12.Erzha, E. L., Sudarma, M., \& Rahman, A. F. (2019). The Effect of Loan and Intellectual Capital on Profitability with Credit Risk as Moderating. Jurnal Economia, 15(2), 159-171.

13.Ghosh, A. (2012). Managing risks in commercial and retail banking: John Wiley \& Sons.

14.Gul, S., Irshad, F., \& Zaman, K. (2011). Factors Affecting Bank Profitability in Pakistan. Romanian Economic Journal, 14(39).

15. Harahap, D. A., \& Hairunnisah, A. I. (2017). PENGARUH NPL, LDR, GCG, NIM, ROA, ROE, CAR, BOPO TERHADAP HARGA SAHAM PADA PERUSAHAAN PERBANKAN YANG TERDAFTAR DI BURSA EFEK INDONESIA DARI TAHUN 2010-2014. THE EFFECT OF NPL, LDR, GCG, NIM, ROA, ROE, CAR, BOPO TOWARDS THE STOCK PRICE IN BANKING COMPANIES LISTED IN INDONESIAN STOCK EXCHANGE OF THE YEAR 2010-2014. Jurnal Dimensi, 6(1).

16. Hendrawati, L., \& Djamaludin, S. (2020). Pengaruh Likuiditas, Pertumbuhan Kredit, Efisiensi, dan Kecukupan Modal Terhadap Profitabilitas. Bulletin of Management and Business, 1(1), 27-35.

17.Hermuningsih, S. (2019). Third Party Funds and Indonesia's Sharia Banking Profitability with Revenue Sharing as Intervening Variable.

18.Hồ, V. N., Đặng, N. H., Trần, T. H., Phạm, Đ. D., \& Hoàng, H. L. (2020). Factors affecting share prices of publicly traded steel companies in Vietnamese security market.

19. Hull, J. (2012). Risk management and financial institutions, + Web Site (Vol. 733): John Wiley \& Sons.

20.Isanzu, J. S. (2017). The Impact of Credit Risk on Financial Performance of Chinese Banks. Journal of International Business Research and Marketing, 2(3).

21.Iskandar, A. S., Che-Yahya, N., \& Ab Wahid, Z. Determinants of Commercial Banks' Profitability in Malaysia Journal of.

22.Islam, M. A., \& Rana, R. H. (2017). Determinants of bank profitability for the selected private commercial banks in Bangladesh: A panel data analysis. Banks \& bank systems(12,№ 3 (cont.)), 179192.

23.Kadioglu, E., Telceken, N., \& Ocal, N. (2017). Effect of the asset quality on the bank profitability. International Journal of Economics and Finance, 9(7), 60-68.

24.Kidane, S. T. (2020). Credit risk management and profitability: empirical evidence on Ethiopian commercial banks. Jurnal Perspektif Pembiayaan dan Pembangunan Daerah, 8(4), 377-386.

25.Koch, T. W., S. Scott MacDonald,Vic Edwards, and Randall E. Duran. (2014). Bank Management. Singapore: Cengage Learning Asia Pte Ltd.

26.Kutum, I. (2017). The Impact of Credit Risk on the Profitability of Banks Listed on the Palestine Exchange. Research Journal of finance and accounting, 8(8), 136-141.

27.Magdalena, A., Marpaung, B. S., \& Indira, E. (2019). The Effects Of Bank Funds Sources On Bank Profitability In Indonesian Stock Exchange. Riset, 1(2), 090-098.

28. Muda, M., Shaharuddin, A., \& Embaya, A. (2013). Comparative analysis of profitability determinants of domestic and foreign Islamic banks in Malaysia. International Journal of Economics and Financial Issues, 3(3), 559. 
29. Munangi, E., \& Bongani, A. (2020). An empirical analysis of the impact of credit risk on the financial performance of South African banks. Academy of Accounting and Financial Studies Journal, 24(3), 1-15.

30.Ozgur, O., \& Gorus, M. S. (2016). Determinants of deposit bank profitability: evidence from Turkey. Journal of Applied Economics and Business Research, 6(3), 218-231.

31.Poudel, S. R. (2018). Impact of credit risk on profitability of commercial banks in Nepal. Journal of Applied and Advanced Research, 3(6), 161-170.

32.Pujiati, P., Zainul Kisman, and Aam Bastaman. (2020). Analysis of Capital Adequacy Ratio, Prime Lending Rate, and Third-Party Funds on Profitability of Commercial Banks in Indonesia, With Liquidity as Intervening Variable. Journal of Economics and Business, 3(1), 172-188. doi:10.31014/aior.1992.03.01.187

33.Qureshi, Muhammad Imran, et al. "Classifications of sustainable manufacturing practices in ASEAN region: A systematic review and bibliometric analysis of the past decade of research." Sustainability 12.21 (2020): 8950.

34.Rwayitare, J. B., Jaya Shukla, and Charles Ruhara. (2016). Credit Risk and Commercial Bank Profitability in Rwanda. International Journal of Advance Research, 4(9), 294-325.

35.Saleh, I., \& Abu Afifa, M. (2020). The effect of credit risk, liquidity risk and bank capital on bank profitability: Evidence from an emerging market. Cogent Economics \& Finance, 8(1), 1814509.

36.Sugiyono. (2013). Quantitative, Qualitative and R \& D Research Methods. Bandung.

37.Titman, S., Athur J. Keown and John D. Martin,. (2018). Financial Management: Principles and Applications. Harlow, United Kingdom: Pearson Education Limited.

38. Wijayanti, E., \& Mardiana, M. (2020). Loan growth and bank profitability of commercial banks in indonesia. AKUNTABEL, 17(1), 38-52. 